\title{
Race-gender differences in serum creatine kinase activity: a study among South Africans
}

\author{
R F GLEDHILL,* C A VAN DER MERWE, $\dagger$ M GREYLING,* M M VAN NIEKERK
}

From the Division of Neurology, Department of Internal Medicine, University of Pretoria; ${ }^{*}$ the Institute of Biostatistics, Medical Research Council; $\nmid$ and the Department of Chemical Pathology, Institute of Pathology, University of Pretoria, $\ddagger$ South Africa

SUMMARY Higher levels of total serum creatine kinase activity have been reported in black compared with white North Americans of the same sex. In a study among South Africans, we found such an interracial difference was notable only for males. The difference was heightened by physical activity. This study affirms the importance of sampling the indigenous population when developing a reference range for total creatine kinase activity.

Several reports from North America have described substantially higher levels of total serum creatine kinase (CK) activity in black adults compared with white adults of the same sex. ${ }^{1-6}$ Such race-gender differences have important implications, as the level of this enzyme is an established laboratory aid for the diagnosis and management of various skeletal muscle disorders. ${ }^{46}$

To develop a reference range for our hospital, we measured levels of total CK activity in healthy black South Africans of both sexes. Simultaneously, we further investigated the relationship between race, gender and CK activity by studying a comparable group of white South Africans. Considering the elevation in total CK activity that may occur during normal (that is, everyday) activity ${ }^{7-9}$ and that invariably follows strenuous recreational activity, ${ }^{10-19}$ particular attention was paid to these variables when designing the study protocol. Part of this study has been briefly reported. ${ }^{20}$

\section{Methods}

\section{Subjects and procedures}

The black male and black female subjects were members of either the nursing or administrative staff at Kalafong Hospital. The white male and white female subjects were University of Pretoria medical students or Institute of Pathology laboratory personnel. All gave informed consent. The sub-

Address for reprint requests: Dr R F Gledhill, Kalafong Hospital, Private Bag X396, Pretoria 0001, South Africa.

Received 9 June 1987 and in revised form 6 August 1987. Accepted 14 August 1987 jects fasted overnight prior to blood sampling. At this time, information was sought as to their present state of health and what medication they were taking regularly. In addition, they were asked whether and, if so, when in the previous 7 days they had undertaken vigorous physical activity and whether they engaged in systematic recreational activity. Female subjects were asked whether they had reason to believe they were pregnant.

Blood sampling and biochemical analyses

Using gentle handling to avoid haemolysis, ${ }^{21}$ blood samples were taken from an antecubital vein with minimal stasis. ${ }^{22}$ Sampling was undertaken before $0830 \mathrm{~h}$. The specimens were delivered directly to the (central) laboratory and analyses were performed the same day (see ref 23). Total serum CK activity was analysed by the Centrifichem System Analyses ${ }^{(\mathbf{R})}$ (Union Carbide Corporation) using Gemstar ${ }^{\mathrm{TM}}$ reagent kits (Electro-Nucleonics International Ltd). Values were estimated at $37^{\circ} \mathrm{C}$.

\section{Statistical analyses}

Correlations were assessed by Spearman's rank correlation coefficient (r). P values of $<0.05$ were considered significant.

\section{Results}

Fifty-four black males, 111 black females, 88 white males and 67 white females were studied. All subjects were in good health and not one was taking regularly medication known to affect total CK activity. ${ }^{24}$ None of the females believed they were pregnant. Frequency distributions of total CK activity are illustrated in the fig; for none of the groups did values conform to a normal distribution. The group mean ages and median values (with ranges) for total CK 

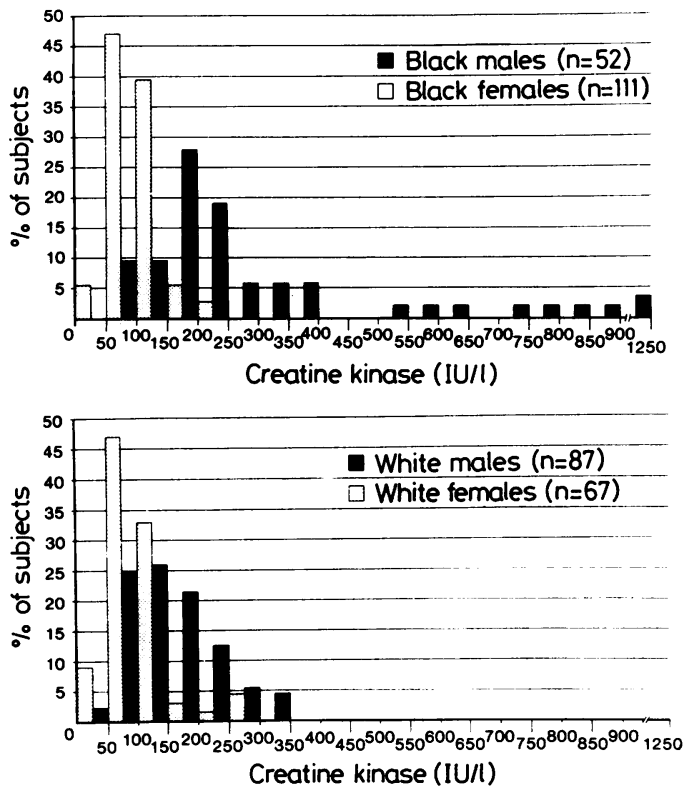

Fig Frequency distribution histograms of total CK activity in black subjects and white subjects. To facilitate illustration, the histograms do not include two black males with values of I536 IU/l and $3170 \mathrm{IU} / \mathrm{l}$ and one white male with a value of $6685 \mathrm{IU} / \mathrm{l}$.

activity were, respectively: black males $27 \cdot 7$ (SD 10.74) years, $216(71-3170)$ IU/1; black females 22.0 (SD 2.37), 97 (23-229); white males 23.1 (SD 3.35), 142 (42-6685); and white females 21.9 (SD 2.67), 93 (37-274).

Each subject was categorised as either an exerciser or a non exerciser. An exerciser was someone engaged in systematic recreational activity and/or had undertaken vigorous physical activity in the previous 7 days. A non exerciser was someone who denied either.
The exercisers were further subdivided into those who had, and those who had not, undertaken vigorous physical activity within the previous $72 \mathrm{~h}$. The number of subjects in each exercise subgroup, together with the $95 \%$ confidence intervals for median values ${ }^{25}(\mathrm{CIs})$ and values for interquartile ranges ${ }^{26}$ for total CK activity, are shown in the table. The CIs were of a higher order in males compared with females of the same race and in black males compared with white males. In the case of female interracial comparisons, no distinctive pattern emerged.

Only for the black males was the correlation between age and total $\mathrm{CK}$ activity significant $(r=$ $-0.434, p=0.001$ ). The mean age of the black male non exercisers was 35.9 (SD 12.96) years and the correlation in this subgroup was $-0.514(p=0.024)$; for the exercisers (both subgroups combined), the corresponding values were 23.2 (SD 5.75) years and $-0.146(p=0.400)$. The significant negative correlation for the black males as a group may therefore be explained by the confounding variable of physical activity.

\section{Discussion}

The results of this study exhibit several features that merit further consideration. Specifically, we foundत̄ that levels of total CK activity were notably higher in males compared with females of the same race and in black males compared with white males; that these phenomena were intensified by physical activity; and that levels were only slightly higher in black femaleso compared with white females.

\section{Males compared with females of the same race}

There is an extensive literature describing higher levels of total CK activity in men compared with women of the same race. ${ }^{13-72728}$ While it is generally

Table Mean ages and median values and ranges of total creatine kinase (CK) activity in the race-gender groups, with $95 \%$ confidence intervals (CI) for median values and values for interquartile (IQ) ranges of total $C K$ activity in the exercise subgroups within each race-gender group

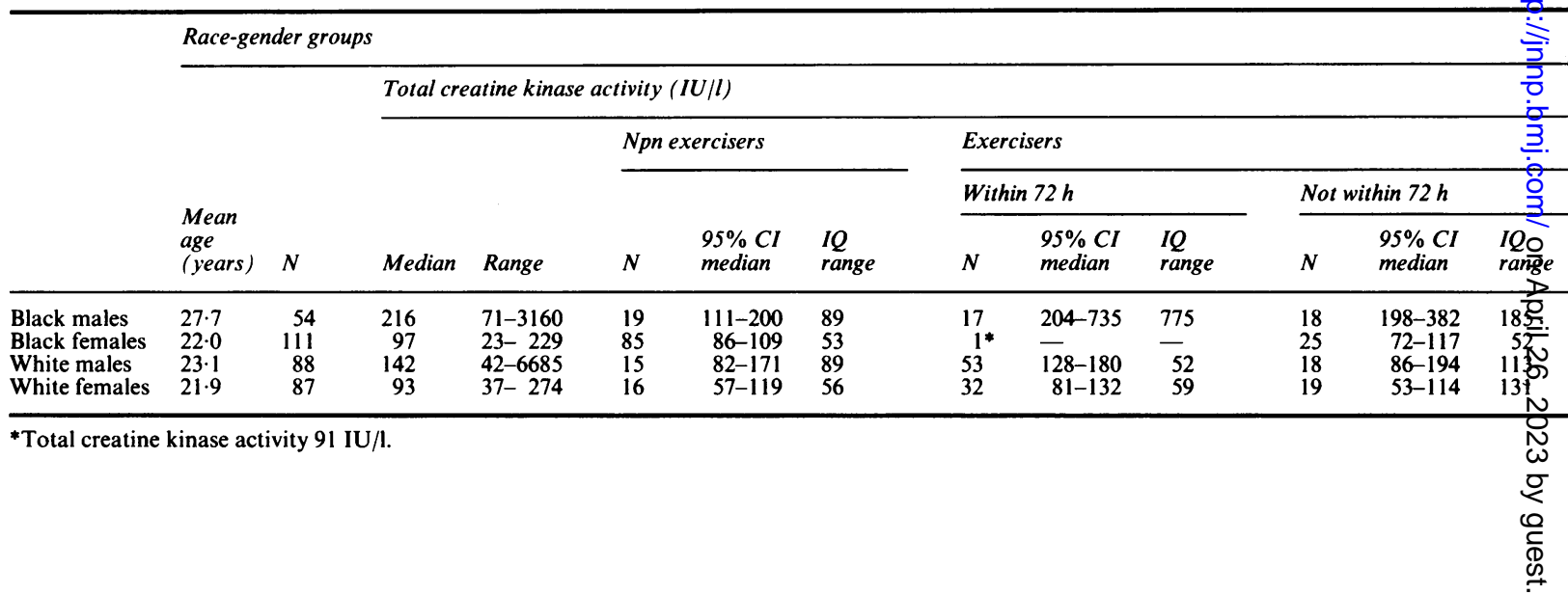


believed that the influence of oestrogens is responsible, ${ }^{17212729-34}$ it is possible that androgens $^{35}{ }^{36}$ may have a role as well. The influence of oestrogens has also been invoked to explain the greater elevation of total CK activity in males following physical activity. ${ }^{16}$ While not all studies have shown this disparity, ${ }^{19} 37$ in our study gender differences were clearly heightened by physical activity. This was observed for blacks and for whites, though most notably among the former.

\section{Black males compared with white males}

The differential effect of physical activity (as well as the greater gender difference between black non exercisers) was due to the comparatively higher values for black males rather than lower values for black females. In seeking to explain this finding as regards both subgroups of male exercisers, consideration must be given to the varied effects of total CK activity of training, ${ }^{1013-1518}$ and to the influence of the duration and intensity of recent physical activity. ${ }^{111215}$ As our study was not designed to address such specific issues, the relative contributions of these factors remain unknown.

Variations in muscle mass have been proposed to account for interracial differences in total CK activity $^{4}$ and such a factor has to be reckoned with to explain the higher values of the black male non exercisers. A recent study failed to substantiate this notion, ${ }^{6}$ however, and a more likely explanation could be the influence of genetic factors. ${ }^{1}$ Not only have twin pair studies shown that interindividual variation in total CK activity is under some degree of genetic control, ${ }^{38}$ but also a consistent trend towards higher values with increasing skin pigmentation has been reported. ${ }^{2}$

The influence of genetic factors (on physical activity effects) also may offer a more rational explanation for the comparatively higher values of the black exercisers.

\section{Black females compared with white females}

The close interracial similarity of values for females most distinguishes our results from those in previous reports. ${ }^{1-6}$ Two circumstances may bear on this discrepancy. Thus, in none of the cited studies can physical activity be wholly excluded as possibly contributing to the substantially higher values among their black females. It also needs to be emphasised that our study involved a population from an entirely different part of the world.

In conclusion, we have affirmed the importance of sampling the indigenous population when developing a reference range for total CK activity. ${ }^{4639}$ In addition, this study has highlighted the need to exclude systematic recreational activity, as well as recent physical activity, when interpreting an elevated value, at least with respect to young adult males.

Permission to study Kalafong Hospital staff was given by the Director of Hospital Services for the Transvaal. We thank Mr AJ Dippenaar and Mrs HJ Symington for arranging access to these persons, $\mathbf{M r}$ J Breder and Mrs L Matzner for technical help and Mrs JJ Edwards for secretarial assistance. Dr G Schott provided valuable criticism of the manuscript.

\section{References}

1 Meltzer HY. Factors affecting serum creatine phosphokinase levels in the general population: The role of race, activity and age. Clin Chim Acta 1971;33:165-72.

2 Meltzer HY, Holy PA. Black-White differences in serum creatine phosphokinase (CPK) activity. Clin Chim Acta 1974; 54:215-24.

3 Van Steirtegham AC, Robertson EA, Zweig MH. Distribution of serum concentrations of creatine kinase $\mathrm{MM}$ and $\mathrm{BB}$ isoenzymes measured by radioimmunoassay. Clin Chim Acta 1979;93:25-8.

4 Wong ET, Cobb C, Umehara MK, et al. Heterogeneity of serum creatine kinase activity among racial and gender groups of the population. Am J Clin Pathol 1983;79:582-6.

5 Miller WG, Gruemer HD, Chinchilli VM. Upper reference limit for creatine kinase. Clin Chem 1985;31:158.

6 Black HR, Quallich H, Gareleck CB. Racial differences in serum creatine kinase levels. Am J Med 1986;81:479-87.

7 Griffiths PD. Serum levels of ATP: Creatine phosphotransferase (creatine kinase). The normal range and effect of muscular activity. Clin Chim Acta 1966;13:413-20.

8 Hudgson P, Gardner-Medwin D, Pennington RJT, Walton JN. Studies of the carrier state in the Duchenne type of muscular dystrophy. Part I. Effect of exercise on serum creatine kinase activity. J Neurol Neurosurg Psychiatry 1967;30:416-9.

9 Nicholson GA, Morgan G, Meerkin M, Strauss E, McLeod JG. The creatine kinase reference interval. An assessment of intraand inter-individual variation. $J$ Neurol Sci 1985;71:225-31.

10 Vejjajiva A, Teasdale GM. Serum creatine kinase and physical exercise. Br Med J 1965;i:1653-4.

11 Fowler WM, Gardner GW, Kazerunian HH, Lauvstad WA. The effect of exercise on serum enzymes. Arch Phys Med Rehabil 1968;49:554-65.

12 Hunter JB, Critz JB. Effect of training on plasma enzyme levels in man. J Appl Physiol 1971;31:20-3.

13 Misner JE, Massey BH, Williams BT. The effect of physical training on the response of serum enzymes to exercise stress. Med Sci Sport 1973;5:86-8.

14 King SW, Statland BE, Savory J. The effect of a short burst of exercise on activity values of enzymes in sera of healthy young men. Clin Chim Acta 1976;72:211-8.

15 Berg A, Haralambie G. Changes in serum kinase and hexose phosphate isomerase activity with exercise duration. Eur $J$ Appl Physiol 1978;39:191-201.

16 Shumate JB, Brooke MH, Carroll JE, Davis JE. Increased serum creatine kinase after exercise: A sex linked phenomenon. Neurology 1979;29:902-4.

17 Smith I, Elton RA, Thomson WHS. Carrier detection in X-linked recessive (Duchenne) muscular dystrophy: Serum creatine phosphokinase values in premenarchal, menstruating, post menopausal and pregnant normal women. Clin Chim Acta 1979;98:207-16.

18 Roti S, Tori E. Guiducci U, et al. Serum concentrations of myoglobin, creatine phosphokinase and lactic dehydrogenase after exercise in trained and untrained athletes. J Sports Med 
1981;21:113-8.

19 Newham DJ, Jones DA, Edwards RHT. Large plasma creatine kinase changes after stepping exercise. Muscle Nerve 1983;6:380-5.

20 Gledhill RF, Van Niekerk MM, Van der Merwe CA. Racial differences in serum creatine kinase activity. Am J Med 1987;83:365-6.

21 Paterson Y, Lawrence EF. Factors affecting serum creatine phosphokinase levels in normal adult females. Clin Chim Acta 1972;42:131-9.

22 Rawle J, Knight JA. Elevated creatine phosphokinase in blood donors. Am J Clin Pathol 1971;56:253-4.

23 Thomson WHS. An investigation of physical factors influencing the behaviour in vitro of serum creatine phosphokinase and other enzymes. Clin Chim Acta 1969;23:105-20.

24 Lott JA, Landesman PW. The enzymology of skeletal muscle disorders. CRC Crit Rev Clin Lab Sci 1984;20:153-90.

25 Bulpitt CJ. Confidence intervals. Lancet 1986;i:494-7.

26 Altman DG, More SM, Gardner MJ, Pocock SJ. Statistical guidelines for contributors to medical journals. $\mathrm{Br} \mathrm{Med} \mathrm{J}$ 1983;i:1489-93.

27 Sweetin JC, Thomson WHS. Revised normal ranges for six serum enzymes: Further statistical analysis and the effects of different treatments on blood specimens. Clin Chim Acta 1973;48:49-63.

28 Norton JP, Clarkson PM, Graves JE, Lichfield P, Kirwan J. Serum creatine kinase activity and body composition in males and females. Hum Biol 1985;57:591-8.

29 Perry TB, Fraser FC. Variability of serum creatine phosphokinase activity in normal women and carriers of gene for Duchenne muscular dystrophy. Neurology 1973;23:1316-23.
Gledhill, Van der Merwe, Greyling, Van Niekerk

30 Satapathy RK, Skinner R. Serum creatine kinase levels in normal females. J Med Genet 1979;16:49-51.

31 Bundey S, Crawley JM, Edwards JH, Westhead RA. Serum creatine kinase levels in pubertal, mature, pregnant and post menopausal women. J Med Genet 1979;16:117-21.

32 Lance RJM, Roses AD. Variation of serum creatine kinase levels with age in normal females: implications for genetic counselling in Duchenne muscular dystrophy. Clin Chim Acta 1981;113:75-86.

33 Cohen L, Morgan J. Diethylstilboestrol effects on serum enzymes and isozymes in muscular dystrophy. Arch Neurol 1976;33:480-4.

34 Cohen L, Morgan J, Bozyk ME. Effects of simultaneous administration of diethylstilboestrol and prednisolone on serum enzymes in Duchenne's muscular dystrophy. $J$ Med 1977;8:123-34.

35 Spaulding WB. Myalgia and elevated creatine phosphokinase with danazol in hereditary angioedema. Ann Int Med 1979;90:854.

36 Sheffer AL, Fearon DT, Austen KF. Clinical and biochemical effects of stanozolol therapy for hereditary angioedema. $J$ Allergy Clin Immunol 1981;68:181-7.

37 Good DJ, Meltzer HY. Effects of isometric exercise on serum creatine phosphokinase activity. Arch Gen Psychiatry 1976;33:1207-11.

38 Metlzer HY, Dorus E, Grunhaus L, Davis JM, Belmaker R. Genetic control of human plasma creatine phosphokinase activity. Clin Genet 1978;13:321-6.

39 Meltzer HY. Interpretation of CK activity. JAMA 1974;229:1169. 